Article

\title{
In-Vitro Evaluation of the Antioxidant and Anti-Inflammatory Activity of Volatile Compounds and Minerals in Five Different Onion Varieties
}

\author{
Rokayya Sami ${ }^{1, * D}$, Abeer Elhakem ${ }^{2}$, Mona Alharbi ${ }^{2}$, Manal Almatrafi $^{1}$, Nada Benajiba $^{3}$, \\ Taha Ahmed Mohamed ${ }^{4,5}$, Mohammad Fikry ${ }^{6}$ (D) and Mahmoud Helal ${ }^{7}$
}

1 Department of Food Science and Nutrition, College of Sciences, Taif University, P.O. 11099, Taif 21944, Saudi Arabia; manal.almatrafi@uconn.edu

2 Department of Biology, College of Science and humanities in Al-Kharj, Prince Sattam Bin AbdulazizUniversity, Al-Kharj 11942, Saudi Arabia; abeer_hamdy24@yahoo.com (A.E.); mh.alharbi@psau.edu.sa (M.A.)

3 Department of Basic Health Sciences, Deanship of Preparatory Year, Princess Nourah Bint Abdulrahman University, P.O. Box 84428, Riyadh 11671, Saudi Arabia; benajibanada@gmail.com

4 College of Life Science, Northeast Agricultural University, Harbin 150030, China; tahamicro12345@gmail.com

5 Soil, Water and Environment Research Institute, Agriculture Research Center, Giza 583121, Egypt

6 Department of Agricultural and Biosystems Engineering, Faculty of Agriculture, Benha University, Moshtohor, Toukh 13736, Egypt; moh.eltahlawy@fagr.bu.edu.eg

check for

updates

Citation: Sami, R.; Elhakem, A.; Alharbi, M.; Almatrafi, M.; Benajiba, N.; Ahmed Mohamed, T.; Fikry, M.; Helal, M. In-Vitro Evaluation of the Antioxidant and Anti-Inflammatory Activity of Volatile Compounds and Minerals in Five Different Onion Varieties. Separations 2021, 8, 57. https://doi.org/10.3390/ separations 8050057

Academic Editors: Ki Hyun Kim and Didier Thiébaut

Received: 18 February 2021

Accepted: 28 April 2021

Published: 1 May 2021

Publisher's Note: MDPI stays neutral with regard to jurisdictional claims in published maps and institutional affiliations.

Copyright: (c) 2021 by the authors. Licensee MDPI, Basel, Switzerland. This article is an open access article distributed under the terms and conditions of the Creative Commons Attribution (CC BY) license (https:/ / creativecommons.org/licenses/by/ $4.0 /)$.
7 Department of Mechanical Engineering, Faculty of Engineering, Taif University, P.O. 11099, Taif 21944,Saudi Arabia; eng_mah_helal@yahoo.com

* Correspondence: rokayya.d@tu.edu.sa

\begin{abstract}
Onions contain high antioxidants compounds that fight inflammation against many diseases. The purpose was to investigate some selected bioactive activities of onion varieties (Yellow, Red, Green, Leek, and Baby). Antioxidant assays and anti-inflammatory activities such as NO production with the addition of some bioactive components were determined and analyzed by using a spectrophotometer. Gas chromatography and mass spectrometry (GC-MS) was used for the volatile compounds, while an Atomic absorption spectrometer was used for mineral determinations. Red variety achieved the highest antioxidant activities. The total flavonoids were between (12.56 and $353.53 \mathrm{mg}$ Quercetin/gin dry weight) (dw) and the total phenol was (8.75-25.73 mg/g dw). Leek, Yellow and Green extracts achieved highly anti-inflammatory values $(3.71-4.01 \mu \mathrm{g} / \mathrm{mL})$ followed by Red and Baby extracts, respectively. The highest contents of sodium, potassium, zinc, and calcium were established for Red onions. Furfuraldehyde, 5-Methyl-2-furfuraldehyde, 2-Methyl-2-pentenal, and 1-Propanethiol were the most predominant, followed by a minor abundance of the other compounds such as Dimethyl sulfide, Methyl allyl disulfide, Methyl-trans-propenyl-disulfide, and Methyl propyl disulfide. The results recommend that these varieties could act as sources of essential antioxidants and anti-inflammatories to decrease inflammation and oxidative stresses, especially red onions that recorded high activities.
\end{abstract}

Keywords: onions; bioactive activities; antioxidant; anti-inflammatory; volatile compounds; minerals

\section{Introduction}

Onions are vital industrial marketable vegetable crops grown on a large scale in different parts of the world [1]. It has many medicinal uses such as cardiovascular diseases, nutrients such as carbohydrates, proteins, some vitamins as vitamin $C_{1}, B_{6}$, and folic acid [2]. It has high effective nutrients as sugars (glucose, fructose, galactose, arabinose) and minerals $(\mathrm{Ca}, \mathrm{Fe}, \mathrm{S})$ with some flavonoid and polyphenolcomponents [3,4]. It is low in sodium and fats with an energy value of $40 \mathrm{kcal} / 100 \mathrm{~g}[5,6]$. The antioxidant activities can be estimated using several in-vitro methods [7,8]. Every method is based on different antioxidant activity, as the facility for free radicals scavenging or lipid peroxidation inhibition. However, 
the total antioxidant activity is difficult to be estimated by one single method because of the phytochemicals complex nature [9,10]. 2,20-azinobis-(3-ethylbenzothiazoline-6-sulfonic acid) (ABTS) and Fluorescence recovery after photobleaching (FRAP, and Free radical scavenging) assay (DPPH) assays are regularly used for measuring the antioxidant activities $[11,12]$. Inflammation plays a vital function in pathogenesis and cardiovascular diseases $[13,14]$. The redox stress is responsible for the activation of the immune cells to reactive nitrogen, oxygen, and relief pro-inflammatory cytokines that cause reparation in pathological and physiological pathways $[15,16]$. Nitric oxide $(\mathrm{NO})$ is a free radical that always results in pathological consequences as chronic inflammation [17]. Besides, the volatile compounds, essential minerals, and phenolic compounds depend on a certain variety to maintain optimal health [5].Volatile compounds exhibit anticancer, antioxidant, antimicrobial, anti-cholesterol, and anti-inflammatory activities. Sulfur compounds such as thiosulfinates, thiosulfonates, mono-, di, trisulfides, and thiopropanal S-oxide are responsible for the flavor, odor after cutting, and mastication [18].

The current study aimed to evaluate a comparative analysis of several bioactive compounds such as flavonoid and phenolic contents, antioxidant activities such as ABTS, DPPH, FRAP, anti-inflammatory activity such as NO production, volatile compounds, and mineral contents of onion varieties.

\section{Material and Methods}

\subsection{Chemical and Cells}

Quercetin, Trolox, Folin-Ciocalteu reagent, Griess reagent, Ascorbic acid, FRAP, ABTS, DPPH, DMEM, DMSO, MTT, LPS, RAW 264.7 cells, and other reagents were from (Sigma, St. Louis, MO, USA).

\subsection{Onion Preparation}

The analyzed samples were five different onion varieties: Yellow and Red (Allium cepa), Green (Allium fistulosum), Leek (Allium ampeloprasum), and Baby (Allium ampeloprasumvar. sectivum), analyzed in January 2020. Onions were obtained from a commercial supermarket in Taif from the Kingdom of Saudi Arabia. Onion samples $(1 \mathrm{~kg} /$ variety) were selected in uniform size, with no sign of microbial infections and mechanical damage. Onions were cleaned, cut into pieces and freeze-dried, milled, packed in $\mathrm{N}_{2}$, and stored at $-80^{\circ} \mathrm{C}$ until the end of the experiments.

\subsection{Antioxidant Extraction}

Onion powder $(2 \mathrm{~g})$ was extracted in $10 \mathrm{~mL}$ of $80 \%$ methanol, sonicated for $30 \mathrm{~min}$ and centrifuged at $\sim 4000 \times \mathrm{g}$ for $30 \mathrm{~min}$, and the supernatant was kept at $4{ }^{\circ} \mathrm{C}$ for antioxidant evaluations.

\subsection{Flavonoid Content}

A total of $30 \mu \mathrm{L}$ aliquots of onion extracts were diluted with a mixture of $(90 \mu \mathrm{L}$ methanol, $6 \mu \mathrm{L}$ of $10 \%$ aluminum chloride, and $6 \mu \mathrm{L}$ of $1 \mathrm{~mol} / \mathrm{L}$ potassium acetate) $[13,19]$. The absorbance was calculated at $415 \mathrm{~nm}$ by using Spectra (Max M2, California, CA, USA) with Quercetin as a standard (mg Qe/g dw). The flavonoid content was evaluated in triplicate.

\subsection{Phenolic Content}

The total phenolic content was evaluated in $10 \mathrm{~mL}$ of $80 \%$ methanol. In total, $0.1 \mathrm{mLof}$ $2 \%$ sodium carbonate, $5 \mu \mathrm{L}$ of Folin-Ciocalteu reagent, and $50 \mu \mathrm{L}$ of the onion extract were mixed, incubated in the dark for $2 \mathrm{~h}$, measured at $750 \mathrm{~nm}$, and calculated as gallic acid equivalents $(\mathrm{mg} / \mathrm{g} \mathrm{dw})[9,20]$. 


\subsection{Total Antioxidant Capacity}

An aliquot of $20 \mu \mathrm{L}$ of onion extracts was blended with a mixture of $0.2 \mathrm{~mL}$ of reagent solution( $28 \mathrm{mM}$ sodium phosphate, $0.6 \mathrm{M}$ sulphuric acid, and $4 \mathrm{mM}$ ammonium molybdate) $[19,21]$. The absorbance was evaluated after cooling at $695 \mathrm{~nm}$ and calculated as Ascorbic Acid Equivalent per mg ( $\mu \mathrm{gAAE} / \mathrm{mg})$.

\subsection{Antioxidant Activity Determinations}

\subsubsection{FRAP Assay}

Of the onion extracts, $100 \mu \mathrm{L}$ were vortexed and incubated at $37^{\circ} \mathrm{C}$ for $30 \mathrm{~min}$ in a water bath then added to $1.9 \mathrm{~mL}$ FRAP reagent. FRAP reagent included a mixture of (300 $\mathrm{mM}$ acetate buffer, $10 \mathrm{mM}$ tripyridyl-s-triazine, $40 \mathrm{mM}$ hydrogen chloride and $20 \mathrm{mM}$ ferric chloridein the ratio 10:1:1) [15,22]. Results were measured after incubation for $10 \mathrm{~min}$ at $593 \mathrm{~nm}$, and calculated as ( $\mu \mathrm{mol} \mathrm{TE} / \mathrm{g} \mathrm{dw})$.

\subsubsection{DPPH Assay}

An amount of 0.2 mLaliquots of DPPH solution between 50 and $2000 \mu \mathrm{M}, 20 \mathrm{~mL}$ methanol were mixed with $0.04 \mathrm{~mL}$ of onion extracts and left in the dark for $30 \mathrm{~min}$ at the ambient temperature $[9,12]$. The results were measured at $517 \mathrm{~nm}$, and calculated as $(\mu \mathrm{mol} \mathrm{TE} / \mathrm{g} \mathrm{dw})$.

\subsubsection{ABTS Assay}

A $(7 \mathrm{mM})$ ABTS solution was mixed with $0.04 \mathrm{~mL}$ of onion extracts under regular shaking at $300 \mathrm{rpm}$ until reaching the green radical. The supernatants were collected and theresults were measured at $734 \mathrm{~nm}$ and calculated as ( $\mu \mathrm{mol} \mathrm{TE} / \mathrm{g} \mathrm{dw})[13,23]$.

\subsection{Anti-Inflammatory Activity}

\subsubsection{Extraction for Cell Culture}

In total, $4 \mathrm{~g}$ aliquots of onion samples were mixed and homogenized in $20 \mathrm{~mL}$ methanol $80 \%$ by using Digital Homogeniser (IkaWerke, Staufen, Germany), combined, and evaporated until dry. Onion extracts were dissolved for a final concentration of $20 \mathrm{mg} / \mathrm{mLin}$ DMSO solution.

\subsubsection{Cell Viability (MTT)}

Mitochondrial respiration of cells has been detected by incubation $\left(1 \times 10^{5}\right.$ cells $\left./ \mathrm{mL}\right)$ for $4 \mathrm{~h}$ with $5 \mathrm{mg} / \mathrm{mL}$ of MTT in 96-well plates after solubilizing in DMSO as $150 \mu \mathrm{L}$ per well and evaluated at $490 \mathrm{~nm}[19,24]$.

\subsubsection{NO Production}

Approximately $0.2 \mathrm{~mL}$ aqueous extract of onion varieties with Griess reagent, incubated for $24 \mathrm{~h}$ and NO production was evaluated at $540 \mathrm{~nm}[13,25]$.

\subsection{Determination of Mineral Compositions}

An aliquant of $(2 \mathrm{~g})$ onions powder of each variety was ashed at $500-550{ }^{\circ} \mathrm{C}$. The white-ash residue was dissolved in $15 \mathrm{~mL}$ of $2 \% \mathrm{HNO}_{3}$, filtered through Whatman 40 filter paper, and adjusted to $10 \mathrm{~mL}$ with distilled water for mineral determinations. Atomic absorption spectrometer (PerkinElmer, AAnalyst 800 ) was used for ( $\mathrm{Na}, \mathrm{K}, \mathrm{Mg}, \mathrm{Zn}, \mathrm{Fe}$, and $\mathrm{Ca}$ ) evaluations [11]. Phosphorus content was evaluated by a spectrophotometer (Pharmacia biotech Ultraspec 4000, Shanghai, China) at $440 \mathrm{~nm}$.

\subsection{Gas Chromatography-Mass Spectrometry (GC-MS) Analysis for Volatile Compounds}

The volatile compounds were detected by GC-MS system by GC 7890A and MSD 5975C (Agilent Technologies, Palo Alto, CA, USA). An aliquant of $(1 \mathrm{~g})$ onions powder of each variety was kept in a warm water, during the equilibration and the extraction periods 15 and $40 \mathrm{~min}$, respectively. HP-5MS capillary column $(30 \mathrm{~m} \times 0.25 \mathrm{~mm} \times 0.25 \mu \mathrm{m})$ was 
used for the evaluations, while helium gas was the carrier gas at a flow rate of $1 \mathrm{~mL} /$ minute. The temperature was performed at $70^{\circ} \mathrm{C}$ for $2 \mathrm{~min}$ and raised to $200{ }^{\circ} \mathrm{C}$ at a rate of $3 \mathrm{~min}$ for 15-18 min [26]. Onion extracts were injected in splitless mode. The individual peaks of volatile compounds were identified by the injection of commercial standards with the help of spectra comparisons such as Wiley 9 MS and NIST 14 (Sigma-Aldrich, Milano, Italy) by comparison of the retention indices against the reference data from the literature and the authentic samples. Data were gained electronically in triplicate from the GC peak areas with no need for any correction factors.

\subsection{Statistical Analysis}

All the experiments were applied to (ANOVA) and analyzed by using SPSS, version 20 (SPSS, California, CA, USA). Significant differences were evaluated as $(p<0.05)$.

\section{Results and Discussion}

\subsection{Total Flavonoid, Phenol, and Antioxidant Contents}

Flavonoid values ranged from (12.56 to $353.53 \mathrm{mgQe} / \mathrm{g} \mathrm{dw}$ ), Leek achieved the highest total flavonoid contents followed by Red and Yellow varieties (Table 1). Green and Baby varieties had lower flavonoid contents of 12.56 and $81.13 \mathrm{mg} Q \mathrm{Qe} / \mathrm{g} \mathrm{dw}$, respectively. Gonzales-Barron and Butler [27] reported similar results for onion total flavonoid content. Total phenol contents ranged from $8.75 \mathrm{mg} / \mathrm{g}$ dwin Green to $25.73 \mathrm{mg} / \mathrm{g}$ dwin Red. Leek and Yellow varieties achieved similar results as 20.35 and $21.61 \mathrm{mM}$ (TEAC), respectively. In a comparison with onion varieties, results were similar to the onion values used in the other study [28]. Leek extract achieved the highest total antioxidant activity of $12.80 \mu \mathrm{g}$ $\mathrm{AAE} / \mathrm{mg}$ dwdue to the polyphenolic and flavonoids compounds [29].

Table 1. Total flavonoid, phenol, and antioxidant.

\begin{tabular}{cccc}
\hline & $\begin{array}{c}\text { Total Flavonoid } \\
\mathbf{m g ~ Q e / g ~ d w}\end{array}$ & $\begin{array}{c}\text { Total Phenol } \\
\mathbf{~ m g / g ~ d w ~}\end{array}$ & $\begin{array}{c}\text { Total Antioxidant } \\
\boldsymbol{\mu g} \text { AAE/mg }\end{array}$ \\
\hline Yellow & $163.20 \pm 11.83^{\mathrm{c}}$ & $21.61 \pm 1.37^{\mathrm{b}}$ & $11.16 \pm 0.35^{\mathrm{c}}$ \\
Red & $253.55 \pm 23.15^{\mathrm{b}}$ & $25.73 \pm 0.74^{\mathrm{a}}$ & $12.27 \pm 0.22^{\mathrm{b}}$ \\
Green & $12.56 \pm 0.36^{\mathrm{e}}$ & $8.75 \pm 0.62^{\mathrm{d}}$ & $5.47 \pm 0.08^{\mathrm{e}}$ \\
Leek & $353.53 \pm 5.64^{\mathrm{a}}$ & $20.35 \pm 0.78^{\mathrm{b}}$ & $12.80 \pm 0.08^{\mathrm{a}}$ \\
Baby & $81.13 \pm 3.55^{\mathrm{d}}$ & $17.54 \pm 2.16^{\mathrm{c}}$ & $9.63 \pm 0.46^{\mathrm{d}}$ \\
\hline
\end{tabular}

Different superscript letters $\mathrm{a}, \mathrm{b}, \mathrm{c}, \mathrm{d}$, e show significant differences by statically analysis $(p \leq 0.05)$.

\subsection{Antioxidant Activity (FRAP-DPPH-ABTS)}

Figure 1 shows that FRAP assay of onion varieties were $(9.61-41.26 \mu \mathrm{mol} \mathrm{TE} / \mathrm{g} \mathrm{dw})$ for Green and Red onions, respectively. The values were in good arrangement with the onion report [30]. DPPH assay results were $(6.83-67.10 \mu \mathrm{mol} \mathrm{TE} / \mathrm{g} \mathrm{dw})$ for Yellow and Red onions, respectively. The study finding was in agreement for DPPH assay [31]. ABTS ${ }^{+}$ assay results were (1.16-7.10 $\mu \mathrm{mol} \mathrm{TE} / \mathrm{g} \mathrm{dw})$ for Green and Red onions, respectively. Santaset al. [30] had reported two different white onions (Calot de Valls and var. Fuentes del Ebro) purchased in a local market which achieved 2.42 and $6.13 \mu \mathrm{mol} \mathrm{TE} / \mathrm{g} \mathrm{dw}$ as (TEAC), respectively. However, antioxidant values depend on different factors as heredities, production processes, environmental surroundings, and genetics [32]. 


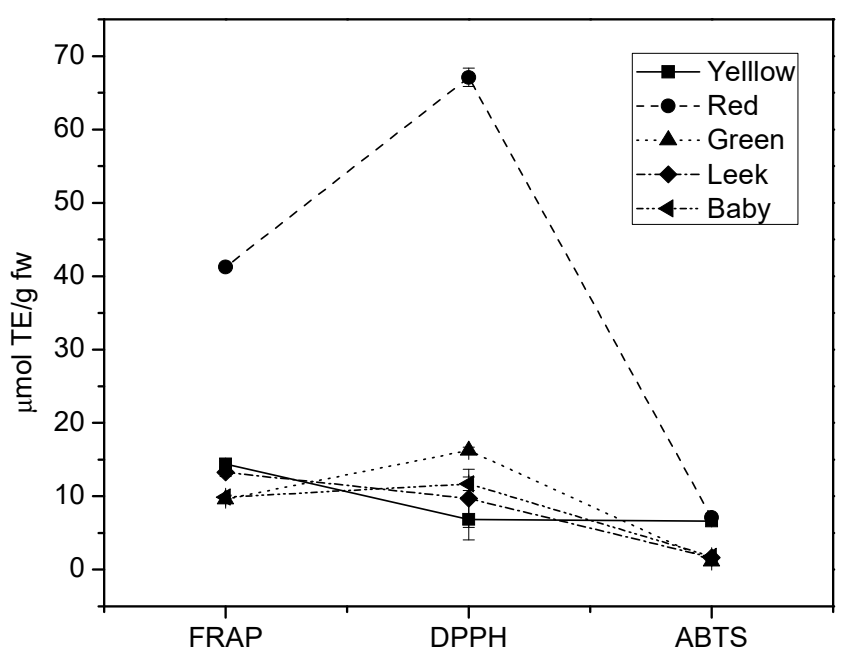

Figure 1. Antioxidant activities of onion varieties.

\subsection{Anti-Inflammatory Activity}

\subsubsection{MTT Reduction}

The cytotoxicities of onion extracts were evaluated in a range of $(0-200 \mu \mathrm{g} / \mathrm{mL})$ (Figure 2). Results show that the concentration range of the cell used did not cause any cytotoxic effect.

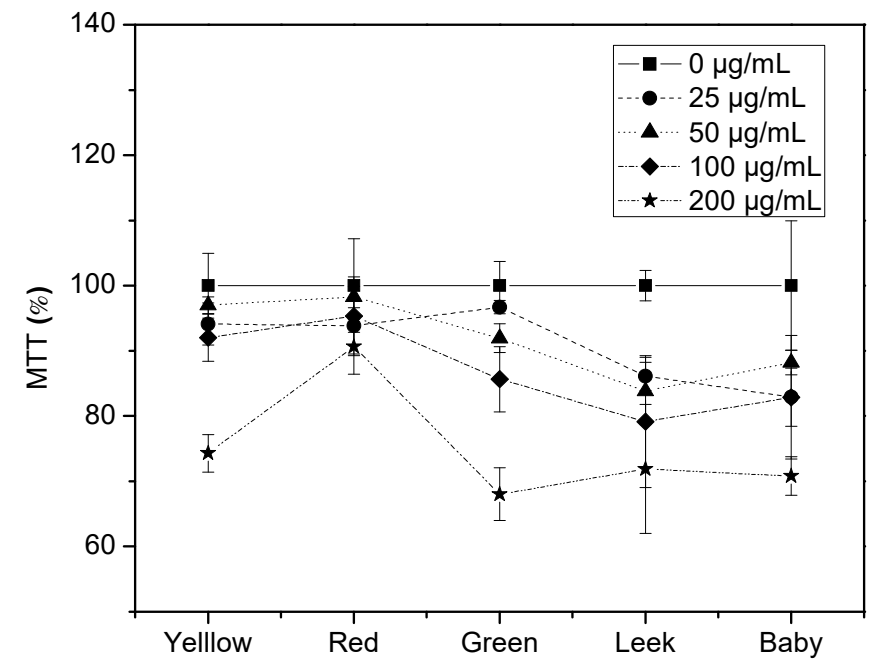

Figure 2. Cell viability of onion varieties.

\subsubsection{NO Production}

$\mathrm{NO}$ production formed a slight quantity of the nitrite after placing the cells for $24 \mathrm{~h}$ in the medium. The medium concentration increased obviously after incubation $24 \mathrm{~h}$ with onion extracts. More NO macrophage production represents a possible toxic effect that causes disease progression [13]. A significant concentration for No production was detected for the five onion extracts (Figure 3). Anti-inflammatory values of onion extracts were in a range of $(0-100 \mu \mathrm{g})$. Leek, Yellow, and Green onions achieved highly anti-inflammatory activity followed by Red and Baby extracts, respectively. These results showed that onion has an obvious influence on free radicals scavenging [33]. NO production grew in the same way with the dose of all onion extracts except in Green onion, while the Green variety showed a different reaction at $50 \mu \mathrm{g} / \mathrm{mL}$ [25]. 


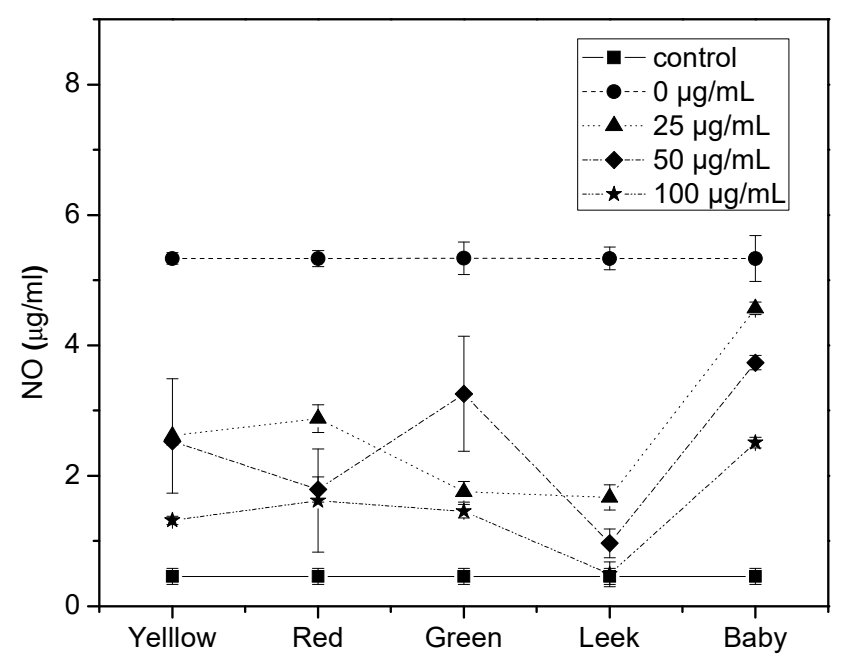

Figure 3. NO production of onion varieties.

\subsection{Mineral Compositions}

The mineral compositions of the five onion varieties are shown in Figure 4 . The quantity of the minerals: sodium, potassium, magnesium, zinc, iron, phosphorus, and calcium have values ranging between (10.7-49.54), (196-266.23), (32.03-60.36), (2.3-15.56), (3.8-8.32), (234.66-343.43), and (399.32-762.65) (mg/100 g DW), respectively. The highest contents of sodium, potassium, zinc, and calcium were established for Red onions. The calcium composition of onion bulbs was high which meant that it can enhance the osmotic regulation, catalytic functions, and energy provisions [5]. Baby onions had the highest content of phosphorus (343.43 mg/100 g DW). Increases in phosphorous and sodium intake have an important role in lowering blood pressure [34,35]. Magnesium and iron compositions in Yellow onions were higher by (60.36 and $8.32 \mathrm{mg} / 100 \mathrm{~g}$ DW) when compared with that in other onion varieties. Magnesium and potassium are very essential for reducing stroke and coronary heart diseases. Iron is an important mineral due to its effective function as catalytic cofactors for protein [25]. Akinwande and Olatunde [36] reported similar values for some mineral compositions in some varieties of onion bulbs.

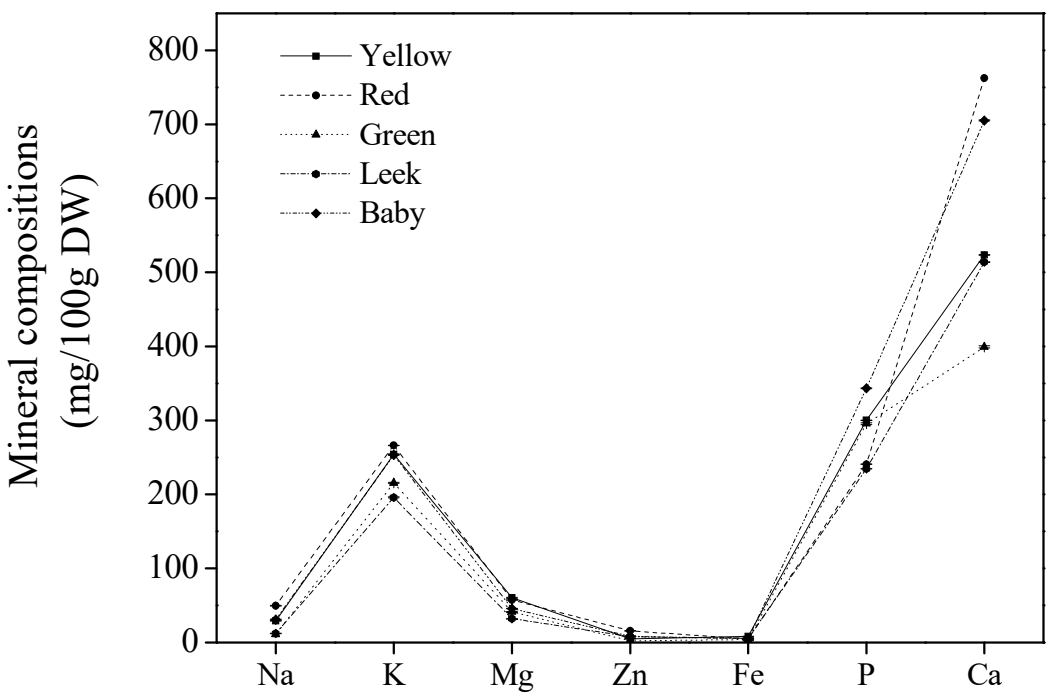

Figure 4. Mineral compositions.

\subsection{Volatile Compounds}

Onion varieties contain cysteine sulfoxides as volatile compounds stored in the intact bulb cytoplasm. After an injury, the alliinase enzyme cleaves cysteine sulfoxides 
into the sulfinic acids then to thiosulfinates that are chemically unstable and responsible for the strong onion odor [37]. Table 2 presents a total of 26 volatile compounds identified by (GC-MS) of five onion varieties. Differences in volatile compounds were noted among onion varieties; Furfuraldehyde, 5-Methyl-2-furfuraldehyde, 2-Methyl-2-pentenal, and 1-Propanethiol were the most predominant, followed by a minor abundance of the other compounds such as Dimethyl sulfide, Methyl allyl disulfide, Methyl-trans-propenyldisulfide, and Methyl propyl disulfide. Abundant compounds in Green onions were Sulfur dioxide $(0.44 \mathrm{mg} / \mathrm{kg}$ DW) and Methanethiol $(0.23 \mathrm{mg} / \mathrm{kg} \mathrm{DW})$ accompanied with a minor abundance of 2-Methylpentanal $(0.14 \mathrm{mg} / \mathrm{kg}$ DW) and Dimethyl disulfide $(0.13 \mathrm{mg} / \mathrm{kg}$ DW). In comparison with Yellow onions, the abundance of several essential compounds was higher, such as Dimethyl sulfide $(1.18 \mathrm{mg} / \mathrm{kg}$ DW), Methyl allyl disulfide $(2.53 \mathrm{mg} / \mathrm{kg}$ DW), and Methyl-trans-propenyl-disulfide ( $1.32 \mathrm{mg} / \mathrm{kg}$ DW). Red onions have the highest in Carbon disulfide, 1-Propanethiol, and S-Propyl ethanetihoate. 2-Methyl-2-pentenal component was the highest in the Leek variety $(65.87 \mathrm{mg} / \mathrm{kg}$ DW). Moreover, some compounds of Baby onions were present with the highest values, such as Furfuraldehyde (166.32 mg/kg DW), and 5-Methyl-2-furfuraldehyde (105.55 mg/kg DW). On the other hand, some compounds were in lower values or not detected such as 3,3-Thiobis-1-propene, and Dimethyl disulfide. Liu et al. [38] reported that 1-propanethiol was the most abundant volatile compound in onion (14.1\%) which was in agreement with the current study. The amount composition of volatile compounds is responsible for the biological activity and flavor $[18,24]$.

Table 2. Volatile compounds.

\begin{tabular}{|c|c|c|c|c|c|}
\hline & Yellow & Red & Green & Leek & Baby \\
\hline Ethyl sulfide & n.d. & $0.01 \pm 0.00^{\mathrm{c}}$ & $0.07 \pm 0.00^{b}$ & $0.06 \pm 0.01^{\mathrm{b}}$ & $0.20 \pm 0.29^{a}$ \\
\hline Dimethyl sulfide & $1.18 \pm 0.26^{\mathrm{a}}$ & $0.19 \pm 0.55^{c}$ & $0.06 \pm 0.00^{\mathrm{d}}$ & $0.17 \pm 0.06^{c}$ & $1.12 \pm 0.27^{b}$ \\
\hline 3,3-Thiobis-1-propene & $0.07 \pm 0.08^{\mathrm{a}}$ & n.d. & n.d. & $0.04 \pm 0.04^{b}$ & $0.01 \pm 0.07^{\mathrm{c}}$ \\
\hline n-Propyl cis-1-propenyl sulfide & $0.06 \pm 0.34^{\mathrm{a}}$ & $0.02 \pm 0.54^{b}$ & n.d. & $0.03 \pm 0.05^{b}$ & $0.01 \pm 0.34^{b}$ \\
\hline Methyl allyl disulfide & $2.53 \pm 0.54^{\mathrm{a}}$ & $1.89 \pm 0.88^{b}$ & $1.45 \pm 0.88^{c}$ & $0.06 \pm 0.09 \mathrm{e}$ & $0.99 \pm 0.53^{d}$ \\
\hline Diethyl disulfide & n.d. & $0.02 \pm 0.29^{a}$ & $0.01 \pm 0.55^{b}$ & $0.02 \pm 0.09^{\mathrm{a}}$ & $0.01 \pm 0.01^{b}$ \\
\hline Methyl-trans-propenyl-disulfide & $1.32 \pm 0.21^{\mathrm{a}}$ & $1.19 \pm 0.29 \mathrm{~b}$ & $0.98 \pm 0.55^{c}$ & $0.07 \pm 0.00^{\mathrm{d}}$ & $1.30 \pm 0.09^{a}$ \\
\hline Methyl propyl disulfide & $1.12 \pm 0.41^{\mathrm{c}}$ & $2.22 \pm 0.07^{b}$ & $0.04 \pm 0.44^{\mathrm{d}}$ & $2.17 \pm 0.05^{b}$ & $5.21 \pm 0.00^{\mathrm{a}}$ \\
\hline Propionaldehyde & $16.87 \pm 0.59^{b}$ & $6.44 \pm 0.34^{\mathrm{d}}$ & $5.98 \pm 0.54 \mathrm{e}^{\mathrm{e}}$ & $12.66 \pm 0.44^{\mathrm{c}}$ & $48.16 \pm 1.05^{\mathrm{a}}$ \\
\hline 2-Methyl-2-pentenal & n.d. & $3.87 \pm 0.53^{\mathrm{d}}$ & $46.88 \pm 0.88^{b}$ & $65.87 \pm 1.54^{\mathrm{a}}$ & $39.00 \pm 1.03^{c}$ \\
\hline Furfuraldehyde & $39.65 \pm 0.17^{\mathrm{e}}$ & $82.65 \pm 0.53^{d}$ & $113.65 \pm 0.88^{b}$ & $98.65 \pm 0.88^{c}$ & $166.32 \pm 1.05^{\mathrm{a}}$ \\
\hline 5-Methyl-2-furfuraldehyde & $88.87 \pm 0.29^{b}$ & $68.86 \pm 0.29^{c}$ & $13.65 \pm 0.55^{\mathrm{e}}$ & $35.77 \pm 0.55^{\mathrm{d}}$ & $105.55 \pm 0.19^{\mathrm{a}}$ \\
\hline 1-Propanethiol & $8.09 \pm 0.07^{\mathrm{e}}$ & $14.11 \pm 0.07^{\mathrm{a}}$ & $10.08 \pm 0.00^{c}$ & $13.10 \pm 0.55^{b}$ & $9.19 \pm 0.55^{\mathrm{d}}$ \\
\hline Dimethyl disulfide & $0.12 \pm 0.34^{b}$ & $0.10 \pm 0.03^{c}$ & $0.13 \pm 0.00^{\mathrm{a}}$ & n.d. & n.d. \\
\hline 2-Methylpentanal & $0.10 \pm 0.53^{c}$ & $0.11 \pm 0.05^{b}$ & $0.14 \pm 0.00^{\mathrm{a}}$ & $0.10 \pm 0.50^{c}$ & n.d. \\
\hline (E)-Hex-2-enal & $0.11 \pm 0.20^{\mathrm{e}}$ & $0.32 \pm 0.02^{\mathrm{a}}$ & $0.28 \pm 0.01^{b}$ & $0.21 \pm 0.55^{\mathrm{d}}$ & $0.24 \pm 0.88^{c}$ \\
\hline (Z)-Hex-3-en-1-ol & $0.20 \pm 0.56^{\mathrm{d}}$ & $0.24 \pm 0.00^{\mathrm{a}}$ & $0.21 \pm 0.00^{\mathrm{c}}$ & $0.20 \pm 0.00^{\mathrm{d}}$ & $0.22 \pm 0.29^{b}$ \\
\hline (E)-Hex-3-en-1-ol & $0.75 \pm 0.52^{b}$ & $0.90 \pm 0.01^{\mathrm{a}}$ & $0.71 \pm 0.01^{\mathrm{c}}$ & $0.54 \pm 0.05^{\mathrm{d}}$ & $0.32 \pm 0.29^{\mathrm{e}}$ \\
\hline Propyl hydrosulfide & $0.32 \pm 0.44^{\mathrm{c}}$ & $0.33 \pm 0.04^{b}$ & $0.31 \pm 0.06^{\mathrm{d}}$ & $0.40 \pm 0.44^{\mathrm{a}}$ & $0.22 \pm 0.07^{\mathrm{e}}$ \\
\hline S-Propyl ethanetihoate & $0.18 \pm 0.544^{\mathrm{e}}$ & $1.50 \pm 0.05^{\mathrm{a}}$ & $0.99 \pm 0.04^{\mathrm{d}}$ & $1.33 \pm 0.54^{b}$ & $1.30 \pm 0.34^{\mathrm{c}}$ \\
\hline 2,5-Dimethylthiophene & $0.20 \pm 0.51^{b}$ & $0.10 \pm 0.01^{\mathrm{d}}$ & $0.21 \pm 0.06^{\mathrm{c}}$ & $0.20 \pm 0.55^{b}$ & $0.23 \pm 0.87^{\mathrm{a}}$ \\
\hline
\end{tabular}

Different superscript letters a, b, c, d, e show significant differences by statically analysis $(p \leq 0.05)$.

\section{Conclusions}

The results in-vitro studies show the onion potentials to reduce inflammation and oxidative stresses. This study discovers that onion varieties have a highly bioactive effect due to the antioxidant behavior that can be beneficial against inflammation. Volatile components were dominated by Furfuraldehyde, 5-Methyl-2-furfuraldehyde, 2-Methyl-2-pentenal, and 1-Propanethiol, while calcium was the most abundant mineral. 
Author Contributions: Methodology, R.S.; software, M.H.; writing-review and editing, M.H., N.B., R.S., A.E., T.A.M., M.F.; M.A. (Manal Almatrafi) and M.A. (Mona Alharbi); visualization, M.H.; funding acquisition, R.S. and N.B. All authors have read and agreed to the published version of the manuscript.

Funding: This research received no external funding.

Institutional Review Board Statement: Not applicable.

Informed Consent Statement: Not applicable.

Data Availability Statement: Available upon request from the corresponding author.

Acknowledgments: Taif University Researchers Supporting Project Number (TURSP-2020/140), Taif University, Taif, Saudi Arabia. This research was funded by the Deanship of Scientific Research at Princess Nourah Bint Abdulrahman University through the Fast-track Research Funding Program.

Conflicts of Interest: The authors declared no conflict of interest.

\section{References}

1. Barla, S.; Upasani, R. Study on Different Methods of Weed Management in Onion (Allium cepa L.). Curr. J. Appl. Sci. Technol. 2019, 33, 1-7. [CrossRef]

2. Sami, R.; Bushnaq, T.; Radhi, K.; Benajiba, N.; Helal, M. Prevalence of thinness cases and dietary diversity among learners of various education stages in Taif Region, Saudi Arabia. Afr. J. Food Agric. Nutr. Dev. 2020, 20, 17081-17094.

3. Sami, R.; Alshehry, G.; Elgarni, E.; Helal, M. Saudi community care awareness food facts, nutrients, immune system and COVID-19 preventionin TaifCity among different age categories. Afr. J. Food Agric. Nutr. Dev. 2021, 21, 17213-17233.

4. Sharma, K.; Mahato, N.; Nile, S.H.; Lee, E.T.; Lee, Y.R. Economical and environmentally-friendly approaches for usage of onion (Allium cepa L.) waste. Food Funct. 2016, 7, 3354-3369. [CrossRef] [PubMed]

5. Edet, A.; Eseyin, O.; Aniebiet, E. Anti-nutrients composition and mineral analysis of allium cepa (onion) bulbs. Afr. J. Pharm. Pharmacol. 2015, 9, 456-459.

6. Sami, R.; Elhakem, A.; Alharbi, M.; Benajiba, N.; Almatrafi, M.; Helal, M. Nutritional Values of Onion Bulbs with some Essential Structural Parameters for Packaging Process. Appl. Sci. 2021, 11, 2317. [CrossRef]

7. Feng, H.; Sami, R.; Li, Y.; Jiang, L.; Cao, W. High-performance size-exclusion chromatography studies on the formation and distribution of polar compounds in camellia seed oil during heating. J. Zhejiang Univ. Sci. B 2016, 17, 882-891. [CrossRef] [PubMed]

8. Li, Y.; Ma, W.; Qi, B.; Sami, R.; Li, D.; Wang, J.; Feng, H.; Sui, X.; Jiang, L. Blending of Soybean Oil with Selected Vegetable Oils: Impact on Oxidative Stability and Radical Scavenging Activity. Asian Pac. J. Cancer Prev. 2014, 16, 2583-2589. [CrossRef]

9. Elhakem, A.; Benajiba, N.; Khojah, E.; Koko, M.; Sami, R. DPPH, FRAP and TAEC Assays with postharvest cabbage (Brassica Oleracca) parameters during the packaging process. Pak. J. Agric. Sci. 2020, 24, 182-187.

10. Sami, R. Antioxidant Properties of Peptides from Soybean Meal Protein Hydrolysates Evaluated by Electron Spin Resonance Spectrometry. Adv. Environ. Biol. 2017, 11, 12-18.

11. Sami, R.; Alshehry, G.; Ma, Y.; Abdelazez, A.; Benajiba, N. Evaluation of some specific components existences in Okra (Abelmoschus esculentus L. (Moench)) cultivated from different areas. J. Food Nutr. Res. 2019, 7, 155-161.

12. Wang, H.; Sun, Y.; Li, Y.; Tong, X.; Regenstein, J.M.; Huang, Y.; Ma, W.; Sami, R.; Qi, B.; Jiang, L. Effect of the condition of spray-drying on the properties of the polypeptide-rich powders from enzyme-assisted aqueous extraction processing. Dry. Technol. 2019, 37, 2105-2115. [CrossRef]

13. Qiao, G.; Wenxin, D.; Zhigang, X.; Sami, R.; Khojah, E.; Amanullah, S. Antioxidant and anti-inflammatory capacities of pepper tissues. Ital. J. Food Sci. 2020, 32, 265-274.

14. Sami, R.; Khojah, E.; Elgarni, E.; Benajiba, N. Evaluation of Nutritional Status for some Sensitive Sets and it is Relationship to Natural Antioxidants. J. King Abdulaziz Univ. Med Sci. 2016, 24, 1-9. [CrossRef]

15. Abeer, H.; Almatrafi, M.; Benajiba, N.; Koko, M.; Sami, R. Comparative analysis of bioactive compounds, antioxidant and anti-inflammatory activities of apple varieties. Asian J. Plant. Sci. 2021, 20, 61-66.

16. Khojah, E.; Sami, R. Fatty Acids Composition and Oxidative Stability of Peanut and Sesame Oils with the Sensory Evaluation of Mayonnaise Prepared by Different Oils. Assiut J. Agric. Sci. 2016, 47, 460-472.

17. Zhang, D.; Zhang, H.; Lao, Y.; Wu, R.; Xu, J.; Murad, F.; Bian, K.; Xu, H. Anti-Inflammatory Effect of 1,3,5,7-Tetrahydroxy-8isoprenylxanthone Isolated from Twigs of Garciniaesculenta on Stimulated Macrophage. Mediat. Inflamm. 2015, 2015, 350564. [CrossRef]

18. Vivek, K.; Singh, S.S.; Sasikumar, R.; Sami, R. Consumer Preference Study on Combined Ultrasound and Sodium Hypochlorite Treated Fresh cut Kiwifruits Coated with Chitosan Using the Fuzzy Logic Approach. J. Microbiol. Biotechnol. Food Sci. 2021, e4054. [CrossRef]

19. Sami, R.; Li, C.-J.; Zhao, Y.; Li, Y.; Sun, C.-H. Cabbage (Brassica oleracea L. var. capitata) phytochemicals with antioxidant and anti-inflammatory potential. Asian Pac. J. Cancer Prev. 2013, 14, 6657-6662. 
20. Sami, R.; Elhakem, A.; Alharbi, M.; Benajiba, N.; Almatrafi, M.; Abdelazez, A.; Helal, M. Evaluation of Antioxidant Activities, Oxidation Enzymes, and Quality of Nano-Coated Button Mushrooms (Agaricus bisporus) during Storage. Coatings 2021, 11, 149. [CrossRef]

21. Prasad, N.; Yang, B.; Kong, K.W.; Khoo, H.E.; Sun, J.; Azlan, A.; Ismail, A.; Romli, Z.B. Phytochemicals and antioxidant capacity from Nypa fruticans Wurmb. fruit. Evid. Based Complementary Altern. Med. 2013, 2013, 154606. [CrossRef]

22. Al-Smadi, M.; Al-Momani, F. Synthesis, characterization and antimicrobial activity of new 1, 2, 3-selenadiazoles. Molecules 2008, 13, 2740-2749. [CrossRef] [PubMed]

23. Sami, R.; Elhakem, A.; Alharbi, M.; Benajiba, N.; Fikry, M.; Helal, M. The combined effect of coating treatments to nisin, nano-silica, and chitosan on oxidation processes of stored button mushrooms at $4{ }^{\circ} \mathrm{C}$. Sci. Rep. 2021, 11, 1-9. [CrossRef]

24. Van Tonder, A.; Joubert, A.M.; Cromarty, A.D. Limitations of the 3-(4, 5-dimethylthiazol-2-yl)-2, 5-diphenyl-2H-tetrazolium bromide (MTT) assay when compared to three commonly used cell enumeration assays. BMC Res. Notes 2015, 8, 1-10. [CrossRef] [PubMed]

25. Lee, J.-K.; Murakami, A.; Watanabe, S.; Ohigashi, H. Suppressive properties of extracts from Japanese edible plants regarding nitric oxide generation. Asian Pac. J. Cancer Prev. 2009, 10, 263-272. [PubMed]

26. Sami, R.; Jiang, L.; Li, Y.; Ma, Y.; Jing, J. Evaluation of Fatty Acid and Amino Acid Compositions in Okra (Abelmoschus esculentus) Grown in Different Geographical Locations. BioMed Res. Int. 2013, 2013, 574283. [CrossRef] [PubMed]

27. Gonzales-Barron, U.; Butler, F. A comparison between the discrete Poisson-gamma and Poisson-lognormal distributions to characterise microbial counts in foods. Food Control 2011, 22, 1279-1286. [CrossRef]

28. Nile, S.H.; Nile, A.S.; Keum, Y.-S. Total phenolics, antioxidant, antitumor, and enzyme inhibitory activity of Indian medicinal and aromatic plants extracted with different extraction methods. 3 Biotech. 2017, 7, 1-10. [CrossRef]

29. Sami, R.; Almatrafi, M.; Elhakem, A.; Alharbi, M.; Benajiba, N.; Helal, M. Effect of Nano Silicon Dioxide Coating Films on the Quality Characteristics of Fresh-Cut Cantaloupe. Membranes 2021, 11, 140. [CrossRef]

30. Santas, J.; Carbo, R.; Gordon, M.; Almajano, M. Comparison of the antioxidant activity of two Spanish onion varieties. Food Chem. 2008, 107, 1210-1216. [CrossRef]

31. Lu, X.; Wang, J.; Al-Qadiri, H.M.; Ross, C.F.; Powers, J.R.; Tang, J.; Rasco, B.A. Determination of total phenolic content and antioxidant capacity of onion (Allium cepa) and shallot (Allium oschaninii) using infrared spectroscopy. Food Chem. 2011, 129, 637-644. [CrossRef]

32. Eldib, R.; Khojah, E.; Elhakem, A.; Benajiba, N.; Helal, M. Chitosan, Nisin, Silicon Dioxide Nanoparticles Coating Films Effects on Blueberry (Vaccinium myrtillus) Quality. Coatings 2020, 10, 962. [CrossRef]

33. Curti, V.; Di Lorenzo, A.; Dacrema, M.; Xiao, J.; Nabavi, S.M.; Daglia, M. In vitro polyphenol effects on apoptosis: An update of literature data. Semin. Cancer Biol. 2017, 46, 119-131. [CrossRef] [PubMed]

34. Elliott, P.; Kesteloot, H.; Appel, L.J.; Dyer, A.R.; Ueshima, H.; Chan, Q.; Brown, I.J.; Zhao, L.; Stamler, J. Dietary phosphorus and blood pressure: International study of macro-and micro-nutrients and blood pressure. Hypertension 2008, 51, 669-675. [CrossRef]

35. Houston, M.C.; Harper, K.J. Potassium, magnesium, and calcium: Their role in both the cause and treatment of hypertension. J. Clin. Hypertens. 2008, 10, 3-11. [CrossRef]

36. Akinwande, B.; Olatunde, S. Comparative evaluation of the mineral profile and other selected components of onion and garlic. Int. Food Res. J. 2015, 22, 332-336.

37. Poojary, M.M.; Putnik, P.; Kovačević, D.B.; Barba, F.J.; Lorenzo, J.M.; Dias, D.A.; Shpigelman, A. Stability and extraction of bioactive sulfur compounds from Allium genus processed by traditional and innovative technologies. J. Food Compos. Anal. 2017, 61, 28-39. [CrossRef]

38. Liu, M.; Su, Y.; Guo, Y. Determination of highly volatile compounds in fresh onion (Allium cepa L.) by room-temperature enrichment headspace-trap coupled to cryotrapping GC-MS. Sep. Sci. Plus 2018, 1, 530-538. [CrossRef] 